\title{
New Versailles or a Velvet Revolution? Brexit and the Exits of Central and Eastern European History, 1916-2016
}

\author{
Ferenc Laczó and Mate Rigo
}

This essay situates Brexit in the context of the first and the last moments of rupture in twentiethcentury Europe: the First World War and the ensuing collapse of Central European empires, on the one hand, and the secession of East European states from the Soviet sphere in and right after 1989, on the other. Both periods were substantially different from Brexit yet produced, not unlike the potential repercussions of the United Kingdom's exit from the European Union, the disintegration of diplomatic alliances and political regimes that had existed for over forty years. The first part of the essay will focus on the relationship of the United Kingdom and Wilhelmine Germany, the major challenger of the status quo as codified by international law at the time. The second part of the essay concentrates on the Eastern European states that were pivotal to the remaking of the continent after 1989.

The questions driving the two parts of this contribution include: under which conditions was the exit from the dominant European order possible in the 1910s and 1990s, respectively? Why did advocates of rupture package discontinuity as the reassertion of continuity? Moreover, why did the larger entity permit its challenger's exit? Finally, what were the short-term legacies of the two ruptures? Differences between the end of the First World War, the Cold War and the UK's exit from the EU notwithstanding, this essay notes that Brexit might have more in common with the situation of Germany and much of East Central Europe during and after the First World War, rather than with the 'annus mirabilis' of Eastern European states that gained full independence from the Soviet Union after 1989.

\section{One Hundred Years Before: 1916-2016}

Are there any similarities between Central and East Central Europe's position during and after the First World War and the potential outcome of Brexit for the United Kingdom? Comparisons of different time periods and historical contexts are best made with caution, as incontestable parallels are difficult to find. Nevertheless, the rise of economic protectionism, populism and national isolationism, along with the popularity of the idea of national sovereignty and selfdetermination in the 1910s, are reminiscent of what might be termed the 'Brexit moment' set in motion in 2016. Furthermore, the First World War provided the first instance in twentiethcentury European history for the loosening of economic and political ties between the United Kingdom and most of Central and East Central Europe, which suggests commonalities with the potential consequences of Brexit.

The outbreak of the First World War in 1914 dealt a severe blow to the relations of the United Kingdom, its allies and the Central Powers. The contours of the post-war order only started to solidify after 1916, following two years of bitter warfare. At the time, the UK was actively engaged in the remaking of the European order. As Isabel Hull has demonstrated, UK engagement was in part a reaction to the radicalism with which Germany and its allies fought the war and thus undermined the rules of pre-war international relations. The allies' 1916 Paris Economic 
Conferences already attempted to solve Europe's economic and political problems without Germany. Some of the recommendations formulated by the economic conferences made it into the Treaty of Versailles and other peace treaties, even if the rapprochement between Germany and the former Allied powers in the 1920s eventually undercut the most radical plans of the 1916 convention.

How did Allied diplomats envision post-war Europe in the midst of the First World War? First, Germany and Austria-Hungary were to be subjected to a 'special régime' of punitive tariffs and excluded from the economic and political alliance among the UK, France, Belgium and Italy. Europe was to become a smaller but politically and economically more cohesive unit. Second, this new European alliance renounced the pre-war practice of free trade and proposed that its members secure 'raw materials and manufactured articles essential to the normal development of their economic activities' (1916 conference resolution).

In 1916 British diplomats found it easy to conceive of the exclusion of Germany and its allies from the post-war order. The amount of British investments in Central and East Central Europe were miniscule compared to the UK's colonial commitments. The British Empire could remain a global power and London a global financial hub, even after the UK severed its ties with the Central Powers; notably, the UK was represented at the 1916 Paris Economic Conference on the future of Europe by Bonar Law, secretary of state for the colonies. By contrast, Germany was seriously affected by the resolutions of the Paris Economic Conference, not least by the expropriation of enemy property carried out after the Conference. Already two years earlier, when the First World War broke out, German investments in the UK and other Allied states totalled around 28 billion gold marks, considerably more than the losses later suffered by British firms in Germany, as the work of Volker Berghahn and Daniela Caglioti demonstrates.

Surprisingly, given the clear break in international economic cooperation and the global order as a result of the war, the UK and much of the rest of Western Europe attempted to sideline the rupture after 1918 by reasserting continuities with the pre-1914 'economic Eldorado' (John Maynard Keynes), and even attempted to 'recast bourgeois Europe' after the pre-war era, as Charles Maier explained. A return to this purported 'golden age of security', Stefan Zweig's label for the pre-1914 period, however, was not an option for East Central European states, just as a 'return' to pre-Brexit Britain will prove impossible for the United Kingdom. Attempts by Eastern European states after 1989 to return to their supposedly 'normal path' of development after four decades of Soviet rule offer no hopeful scenarios in this regard either.

Although the Paris peace treaties delivered on the promise of national sovereignty for the majority of East Central Europeans (aside from East Central Europe's sizable post-1918 minorities), their exit from the crumbling German and Habsburg empires came at the price of diminished prospects for economic prosperity (with the exception of Czechoslovakia) and reduced geopolitical significance. In addition, after 1918 the successor states of Austria-Hungary and Germany were confronted with an economically protectionist Western Europe and an isolationist United States, and thus with no viable alternatives to the old imperial customs units. If Central European states' 'exits' from Austria-Hungary and Germany after 1918 offer any lessons for post-Brexit Britain, it might be that regaining national sovereignty means diminished potential to counter adverse geopolitical processes.

The main difference that sets the 2010s apart from the 1910 s is the radically different geopolitical position of both continental Europe and the United Kingdom. At present, neither a shrunken Europe nor the UK can hope to enjoy a privileged global position, unlike during and after the 'deluge' of the First World War, when the Allies and the United States remained global hegemons despite the onset of Europe's political, military and economic 'provincialisation'. (Adam Tooze). 


\section{Abrupt Secessions and their Consequences}

The unexpected and abrupt exit of East European satellite states from the Soviet realm in 198991 and the ongoing pursuit of Brexit both show conspicuous similarities with recent patterns of new secessionism within states. In the past roughly three decades, the rise of autonomist and even secessionist movements among wealthier parts of larger political entities has emerged as a major trend. Slovenia, Flanders, Catalonia and Northern Italy (Padania in the lingo of its propagators) offer comparable examples, even if the consequences for Yugoslavia, Belgium, Spain and Italy have substantially differed. The representatives of such movements tend to claim that their freedoms are compromised by insufficiently democratic larger state structures. In an unmistakable spirit of welfare chauvinism, they recurrently allude to the fact that their resources are being drained by the mechanisms of redistribution in place supposedly favouring poorer regions.

It does not require us to falsely equate the different guiding spirits and political ambitions behind 1989 and other instances of secessionism to realise that in all these cases, after the gradual growth of disaffection, the wealthier but never seamlessly integrated geographical parts chose institutional rupture. Campaigners for Brexit have argued that in the post-Brexit UK true British political and economic traditions are going to trump the 'alien' and 'superimposed' European ones. It was in a comparable vein that supporters of the East European post-89 transitions suggested that, after decades of foreign imposition and an allegedly forced detour from their 'national path,' their countries' quintessentially national and European traditions could finally become dominant again. For instance, at the reburial ceremony of Imre Nagy in June 1989, Viktor Orbán spoke of the unchanging aim of the Hungarians to end 'Russian occupation and the communist dictatorship' in their country and 'realise European bourgeois democracy'.

Despite their notably different politics, secessionist parties in both the UK and Eastern Europe aimed to consciously disrupt and ultimately annul the institutional relations in place with little concern for the costs. In both cases, the 'secessionist' movements had little inclination to discuss in a realistic manner the original historical reasons behind the Sovietisation of the 1940s and the British entry into the Union in the 1970s, respectively. Through a wilful act of dichotomising European vs. Soviet and UK vs. European history and civilisation, the supporters of both secessions packaged cases of rupture as reasserting cultural-political continuity.

Equally conspicuously, in both examples the larger entity threatened with losing key areas of its realm remained surprisingly permissive, despite the momentous potential consequences of the ongoing changes for the remaining Union as a whole. Gorbachev famously ended the Cold War on an idealistic note, not only allowing the satellite states to depart peacefully and largely on their own terms but, in a puzzling act contradicting decades of Soviet Realpolitik, assented to major Western requests related to Germany without demanding proportionate counter concessions. Similarly, as Tim Shipman has noted, the EU leadership was unwilling to contemplate a truly political response to the emergency and made no special effort to convince the UK to remain in the Union prior to the referendum, only to continue - much more understandably - its strategy of strictly enforcing conditions thereafter. Eastern European nations thus departed from the Soviet Bloc under extraordinarily fortunate circumstances, whereas the UK is chasing a beneficial deal that may be impossible to achieve, not least since the European Union is unlikely to collapse as imminently after Brexit as the Soviet Union did after the collapse of the Soviet Bloc in 1989. What nonetheless remains similar in the two cases is that a symbolic political claim overrides economic considerations: the potential economic strength of an independent national unit in the age of globalisation appears exaggerated and the negative impact of losing access to major markets greatly underestimated.

Since nearly three decades have passed since 1989, we can study the mid-term consequences for Eastern Europe of the dissolution of the Soviet realm and reflect - mutatis mutandis - on their potential lessons for the ongoing Brexit-related discussions. Eastern Europeans left the 
Second World to join some of the most advanced economies in the First, hoping for fast-paced convergence, whereas the UK is departing from the economically largest and (despite numerous shortcomings and worrying trends) socially most progressive union to perform on its own in a world of neoliberal global capitalism. The direction of change in these two cases may thus be seen as contrary, though the two parties share an element of naive hope regarding one's own side only ever benefitting from future cooperation and competition.

In Eastern Europe, public affirmations of national independence were, ironically, combined with avid participation in the grand European project of pooling sovereignty. A disjuncture between state ideology and the realities of the enlarged Europe quickly emerged. Eager to join the European project on whatever terms were being offered, independentism was nonetheless more than a mere pretence: it made Eastern European societies insufficiently concerned with the international organisation their elites decided to join while it also divided those elites from each other, further weakening their positions at the negotiating table with the EU. The 'accession process' thus largely consigned Eastern European elites to the role of imitators, which - not least since the promised benefits of the reorientation towards and integration into the West have still only partially materialised - yielded to a spirit of resentment and rebellion among members of these elites' second generation.

Whereas the profound break with the Soviet Union and (after 1991) Russia defined the early post-communist years of Eastern European states and led to the under-thematisation of their relations to 'the East', their attitudes and connections to an assertive Russia have re-emerged as a most controversial subject in recent years. If the aforementioned parallels are an indicator, the UK might also continue to struggle with defining a balanced approach to the European Union for many decades to come, beyond wholesale critiques and ignorant endorsements.

Similar to the likely results of Brexit, the collapse of Central European empires and the formation of self-proclaimed nation states in the 1910s, as well as the demise of the 'Second World' around 1989, resulted in the disintegration of international alliance systems and economic regimes. This comparison shows that East Central European states faced a more favourable scenario for exiting the Soviet Bloc than after the demise of the Austro-Hungarian and German empires. Although the UK exit from the European Union offers rarely discussed similarities with the secession of the wealthiest states from the Soviet orbit, the UK's current situation may nonetheless be more comparable to the situation of East Central European states after the First World War, as the latter also had to face economic protectionism, US isolationism and lack of support for their transitions from Western European states. Given the seismic shifts in political and economic landscapes over the course of the last one hundred years and in the most recent decades, neither of these case studies can predict the direction Brexit might take. Those, however, who believe that the UK is experiencing its moment of national liberation and beneficial international reorientation may draw several cautionary tales from the twentiethcentury history of Central and Eastern Europe.

Cite this article: Laczó, F. and Rigo, M. 2019. New Versailles or a Velvet Revolution? Brexit and the Exits of Central and Eastern European History, 1916-2016. Contemporary European History 28: 57-60, doi: 10.1017/S0960777318000814 